\title{
AKSELERASI HILIRISASI PRODUK AGROINDUSTRI BERDAYASAING MENDONGKRAK KESEJAHTERAAN PETANI DAN EKONOMI PEDESAAN
}

\author{
ACCELERATION OF HILIRIZATION OF COMPETITIVENESS AGROINDUSTRY \\ PRODUCTS TO SUPPLY THE FARMER'S WELFARE AND RURAL ECONOMY
}

\author{
Roosganda Elizabeth*, Iwan Setiajie Anugrah \\ Pusat Sosial Ekonomi dan Kebijakan Pertanian, J1. Tentara Pelajar No.3B. Cimanggu. Bogor \\ *E-mail: roosimanru@yahoo.com \\ (Diterima 30-06-2020; Disetujui 26-07-2020)
}

\begin{abstract}
ABSTRAK
Akselerasi hilirisasi produk agroindustri merupakan peralihan ekspor produk raw material ke produk olahan yang berdayasaing dan memenuhi tingginya tuntutan persyaratan produk olahan berkualitas dan higienis (GMP). Di era globalisasi dan teknologi 4.0, diperlukan akselerasi pengembangan produk agroindustri yang berdayasaing dan eksis di pasar global, terkait peningkatan pendapatan dan kesejahteraan petani, pelaku usaha produk olahan. Pentingnya mengubah mindset dengan beralihnya ekspor produk baku menjadi produk agroindustri berdayasaing dengan mengembangkan dan meningkatkan implementasi hilirisasi. Dengan metode deskripsi kualitatif dikemukakan tujuan tulisan secara komprehensif tentang hilirisasi produk agroindustri pisang berdayasaing tinggi diperkaya dengan mereview berbagai hasil kajian dan tulisan terkait. Tahap pengolahan dimulai dari industri rumah tangga, unit usaha kecil dan menengah serta ekspor. Produk olahan dilengkapi dengan data dukung analisis, meliputi kelayakan: teknis, finansial, ekonomi, sosial dan lingkungan, serta dukungan infrastruktur dan kebijakan. Teridentifikasi beberapa kendala, seperti: keterbatasan modal, kontiniutas ketersediaan bahan baku, bargaining position, pemasaran dan SDM pelaku usaha. Pengembangan inovasi teknologi, investasi dan SDM pelaku usaha melalui pengembangan produk agroindustri diprediksi mampu menjadi "mesin penggerak" kemajuan perekonomian yang tangguh (membangun daerah dengan membangun pertaniannya). Terlebih bila pemberdayaan dan pengembangan kelembagaannya terlaksana sesuai program pembangunannya. Solusinya diprediksi melalui efisiensi, efektifitas pengolahan, kontiniutas bahan baku, kinerja dan kompetensi tenagakerja, permodalan, serta tersedianya agroindustri di sekitar bahan baku diproduksi. Dengan produk agroindustri berdayasaing tinggi, diharapkan: mampu meraih pasar ekspor, mampu menciptakan lapangan kerja dan peningkatan minat tenagakerja muda di pertanian, mampu meningkatkan pendapatan di perdesaan, serta mampu memotori pengembangan hilirisasi perdesaan, sebagai penghela pembangunan pertanian.
\end{abstract}

Kata kunci: hilirisasi, agroindustri, dayasaing, kesejahteraan, nilai tambah, kelembagaan pertanian

\section{ABSTRACT}

The downstream acceleration of agroindustry products is a shift in the export of raw material products to competitive products that are competitive and meet the high demands of quality and hygienic processed product (GMP) requirements. In the era of globalization and technology 4.0, it is necessary to accelerate the development of agroindustrial products that are competitive and exist in the global market, related to increased income and welfare of farmers, business players of processed products. The importance of changing the mindset by shifting exports of raw products to competitive agroindustry products by developing and improving downstream implementation. With the qualitative description method, it is stated the objective of writing comprehensively about the downstreaming of highly competitive banana agro-industry products enriched by reviewing the results of various studies and related papers. The processing phase starts from the home industry, small and medium business units and exports. Processed products are equipped with data to 


\section{AKSELERASI HILIRISASI PRODUK AGROINDUSTRI BERDAYASAING MENDONGKRAK \\ KESEJAHTERAAN PETANI DAN EKONOMI PEDESAAN \\ Roosganda Elizabeth, Iwan Setiajie Anugrah}

support analysis, covering the feasibility of: technical, financial, economic, social and environmental, as well as infrastructure and policy support. Several obstacles were identified, such as: limited capital, continuity of the availability of raw materials, bargaining position, marketing and HR of business actors. The development of technological innovation, investment and business human resources through the development of agro-industrial products is predicted to be a "driving engine" of strong economic progress (to develop regions by developing agriculture). Especially if the empowerment and institutional development is carried out according to the development program. The solution is predicted through efficiency, effectiveness of processing, continuity of raw materials, performance and competence of labor, capital, and the availability of agro-industry around the raw materials produced. With high competitiveness agro-industry products, it is expected to: be able to reach the export market, be able to create jobs and increase the interest of young workers in agriculture, be able to increase income in rural areas, and be able to drive rural downstream development, as a defender of agricultural development.

Keywords: hilirization, agroindustry, competitiveness, welfare, value added, agricultural institutions

\section{PENDAHULUAN}

Pendapatan dari raw material panen usahatani sangatlah minim, jika diolah menjadi produk olahan, menghasilkan nilai tambah dan nilai jual lebih tinggi. Untuk pencapaian nilai tambah produk olahan yang bermutu, signifikan dan berdayasaing tinggi, maka sangat dibutuhkan efisiensi, efektivitas dan optimalisasi peran agroindustri sebagai strategi proses hilirisasi produk baku pertanian secara maksimal. Kegiatan hilirisasi agroindustri adalah integrasi berbagai kegiatan dari bahan mentah menjadi produk olahan jadi atau setengah jadi. Pengembangan agroindustri penghasil produk pangan pada dasarnya ditujukan untuk memenuhi kebutuhan produk pangan masyarakat dengan mutu terjamin dan harga yang kompetitif, disamping meningkatkan nilai tambah dan ekspor serta memperluas kesempatan berusaha dan bekerja. Selain dari sisi finansial, nilai tambah (value added) yang diperoleh dari pengembangan agroindustridi perdesaan juga dapat meningkatkan penyerapan tenaga kerja, meningkatlan pengetahuan dan ketrampilan SDM dalam implementasi teknologi pengolahan

Teridentifikasi beberapa kendala, seperti: keterbatasan modal, kontiniutas ketersediaan bahan baku, bargaining position, pemasaran dan SDM pelaku usaha. Pengembangan inovasi teknologi, investasi dan SDM pelaku usaha melalui pengembangan produk agroindustri diprediksi mampu menjadi "mesin penggerak" kemajuan perekonomian yang tangguh (membangun daerah dengan membangun pertaniannya). Terlebih bila pemberdayaan dan pengembangan kelembagaannya terlaksana sesuai program pembangunannya. 
Solusinya diprediksi melalui efisiensi, efektifitas pengolahan, kontiniutas bahan baku, kinerja dan kompetensi tenaga kerja, permodalan, serta tersedianya agroindustri di sekitar bahan baku diproduksi.

Di era globalisasi, terbuka luasnya peluang pasar bagi produk perdagangan, termasuk produk olahan berbasis pertanian disertai tingginya persaingan dan persyaratan kualitas produk. Ekspor produk pertanian seharusnya sudah beralih ke produk olahan. Pada kenyataannya, Indonesia merupakan negara pengekspor bahan mentah (raw material) dan sekaligus mengimpor kembali setelah berbentuk produk olahan (komoditi pangan, hortikultura, perkebunan maupun peternakan) (Rachmat et al, 2012). Indonesia dirugikan karena nilai tambah produk tersebut telah diambil alih oleh negara pengolahnya. Dalam mewujudkan struktur perekonomian yang seimbang, nilai tambah yang diperoleh tidak hanya dari sisi finansial dan penarik pembangunan sektor pertanian. Berdasarkan prinsip liberalisasi, globalisasi perdagangan bertujuan mengeliminasi hambatan perdagangan (barriers to trade) melalui keterbukaan pasar dan harmonisasi dengan penyeragaman standar mutu dan keamanan produk, terkait dinamika dan perubahan lingkungan stratejik domestik dan internasional. Hasil panen seharusnya dijual segera sesudah dipanen supaya tidak rugi karena rusak/busuk (terutama komoditi hortikultura). Peran agroindustri dibutuhkan karena hasil usahatani yang belum sempat dijual atau tidak habis terjual harus diolah agar bisa disimpan, yang tentunya memerlukan biaya tambahan. Pengembangan produk olahan mempunyai keuntungan ganda yaitu: (a) sebagai promosi ekspor dan sekaligus substitusi impor, (b) menciptakan nilai tambah pertanian, (c) menciptakan lapangan kerja industri, dan (d) meningkatnya adopsi teknologi.

Diperlukannya peningkatan nilai tambah produk pertanian dan pengembangan perdagangan produk pertanian olahan, pengembangan dan peningkatan agroindustri produk olahan melalui akselerasi kinerja hilirisasi pertanian harus terimplementasi dan berkesinambungan.

Teknologi merupakan salah satu faktor menunjang keberhasilan pengembangan agroindustri peningkatan nilai tambah melalui hilirisasi agroindustri produk. Nilai tambah yang diperoleh dari pengembangan agroindustri diolah 
menjadi berbagai jenis produk tidak hanya dari sisi finansial, tetapi juga dalam aspek: (i) terserapnya sejumlah tenaga kerja; (ii) peningkatan pengetahuan dan ketrampilan SDM dalam teknologi pengolahan; (iii) terbukanya peluang usaha pengolahan produk olahan; (iv) meningkatnya akses terhadap informasi di luar desa; serta yang terpenting (v) meningkatnya pertumbuhan ekonomi; dan selanjutnya akan (vi) meningkatkan pendapatan dan mensejahterakan pelaku usahanya terutama petani pisang.

Dengan metode deskripsi kualitatif dikemukakan tujuan tulisan secara komprehensif tentang hilirisasi produk agroindustri pisang berdayasaing tinggi diperkaya dengan mereview berbagai hasil kajian dan tulisan terkait. Tahap pengolahan dimulai dari industri rumah tangga, unit usaha kecil dan menengah serta ekspor. Produk olahan dilengkapi dengan data dukung analisis, meliputi kelayakan: teknis, finansial, ekonomi, sosial dan lingkungan, serta dukungan infrastruktur dan kebijakan.

\section{METODE PENELITIAN}

Sektor pertanian primer sangat dipengaruhi oleh industri, sistem perdagangan dan distribusi input produksi. Kinerja pertanian dan industri pertanian dipengaruhi oleh pola pengembangan agrodindustri. Turunnya permintaan ekspor Indonesia yang diprediksi terjadinya perlambatan ekonomi global. Seiring era globalisasi ekonomi saat ini, dimana ekonomi Indonesia semakin terintegrasi dengan ekonomi global. Terjadinya fenomena turunnya harga beberapa komoditas eskpor pertanian hendaknya menyadarkan semua pihak terhadap pentingnya pelaksanaan pengembangan agroindustri yang terkait erat dengan peningkatan nilai tambah produk olahan berbasis pertanian. Melambatnya kondisi ekonomi global menjadi tantangan bagi perekonomian Indonesia.

Akselerasi kegiatan agroindustri secara konsepsi mampu memberikan nilai tambah bagi produk pertanian. Usaha agroindustri mengubah menjadi barang setengah jadi (intermediate goods) maupun barang konsumsi (final goods). Peningkatan efisiensi dan kualitas produk untuk mendayagunakan secara optimal potensi pasar, yang dapat dilakukan adalah peningkatan perbaikan sistem produksi, pascapanen dan pengolahan, yang tentunya membutuhkan kompetensi SDM yang berkemampuan dan handal, termasuk petani kecil (pelaku usahatani 
sebagai produsen hasil pertanian), peran dan fungsi aktif kelembagaan pertanian. Pemberdayaan dan peran aktif kelembagaan pertanian serta peningkatan kompetensi SDM petani sebagai produsen dan pelaku usaha hilirisasi agroindustri untuk mampu menghasilkan produk olahan serta pemasarannya. Komoditi pertanian unggul dan berdayasaing tinggi berpotensi ekspor di perdagangan internasional, dan diharapkan dapat mewujudkan kesejahteraan petani kecil di era globalisasi sekarang ini.

Tulisan ini merupakan sebagian dari hasil kajian berdasarkan survei untuk mengumpulkan berbagai data dan informasi terkait tujuan penelitian di beberapa sentra pisang. Dengan metode deskripsi kualitatif dikemukakan tujuan tulisan secara komprehensif tentang hilirisasi produk agroindustri pisang berdayasaing tinggi diperkaya dengan mereview berbagai hasil kajian dan tulisan terkait. Sejalan dinamika pasar, pengembangan dan peningkatan keberagaman teknologi untuk mampu menghasilkan jenis dan mutu produk olahan yang diinginkan konsumen. Keberagaman teknologi pengolahan produk pertanian yang meningkat dan berkembang merupakan sumber kekuatan dalam pengembangan produk olahan yang berkualitas dan berdayasaing (Elizabeth. 2017a). Produk olahan yang akan direkomendasikan untuk dikembangkan hendaknya dilengkapi dengan data dukung berupa analisa kelayakan usaha yang meliputi keragaan umum, kelayakan finansial, kelayakan ekonomi, kelayakan sosial dan lingkungan, kelayakan teknis, dukungan infrastruktur dan kebijakan (Rachmat, et al. 2011).

\section{HASIL DAN PEMBAHASAN}

Seiring dinamika dan perkembangan permintaan pasar serta perubahan permintaan konsumen, maka hasil produk olahan masyarakat tradisional menjadi tertinggal dan terdesak oleh produk olahan modern. Dalam rangka peningkatan nilai tambah dan pengembangan pasar ekspor produk olahan pertanian yang berdaya saing tinggi pada era globalisasi, maka Indonesia harus mengembangkan teknologi dan berinovasi untuk menghasilkan keanekaragaman produk olahan. Berbagai permasalahan yang timbul berkaitan dengan ketidakmampuan industri dalam negeri adalah merupakan salah satu kendala serius dalam melakukan kegiatan dan 
pengembangan pengolahan produk terutama yang berbahan baku produk pertanian. Di daerah sentra produksi pisang (Jawa Barat, Jawa Timur, Lampung, Sumut, Kalbar, dan beberapa wilayah lainnya) terindikasi bahwa umumnya aktivitas perdagangan dan pemasaran komoditi pisang masih dalam bentuk buah segar siap konsumsi dan bersifat regional.

Produk olahan hasil agroindustri memberikan keuntungan, seperti: 1) Meningkatkan nilai tambah yang tinggi dibandingkan dalam bentuk segar; 2) Meningkatkan pendapatan petani; 3) Meningkatkan umur penyimpanan sehingga mengurangi kerusakan dan kerugian; 4) Mengubah dalam bentuk produk awet, sehingga dapat memiliki stok yang besar dalam memperkuat posisi tawar menawar; 5) Menyelamatkan dan memanfaatkan hasil panen dalam penganekaragaman (diversifikasi) jenis pangan; 6) Memberikan keuntungan yang lebih tinggi untuk bersaing di pasar dalam negeri dan terutama di pasar global/internasional. Di era globalisasi saat ini, ekonomi Indonesia semakin terintegrasi dengan ekonomi global, sehingga turunnya permintaan ekspor Indonesia berdampak terjadinya perlambatan ekonomi global, menjadi tantangan bagi perekonomian Indonesia.

Seiring terjadinya fenomena turunnya harga beberapa komoditas eskpor pertanian hendaknya menyadarkan semua pihak pada pentingnya pelaksanaan pengembangan agroindustri. Pendekatan pengembangan pertanian seharusnya diarahkan ke pengembangan produk olahan (hilir) dan bukan lagi sekedar pengembangan komoditi, terutama terdapatnya nilai tambah produk olahan yang perolehannya jauh lebih tinggi dibanding produk primer. Pendekatan lebih difokuskan pada nilai tambah produk melalui pengembangan agroindustri yang mengolah hasil pertanian menjadi produk antara, produk semi akhir dan yang utama adalah produk akhir (finished product) berdaya saing. Kebijakan pengembangan agroindustri dinilai strategis meningkatkan pendapatan dan dapat membuka lapangan pekerjaan.

\section{URGENSI \\ HILIRISASI PISANG}

IMPLEMENTASI AGROINDUSTRI

Indonesia memiliki keragaman jenis dan teknologi pengolahan hasil produk berbahan baku pisang, namun teknik pengolahannya masih didominasi oleh cara-cara tradisional dan umumnya merupakan bagian dari kearifan lokal. 
Seiring dengan dinamika dan perkembangan permintaan pasar serta perubahan permintaan konsumen, maka hasil produk olahan masyarakat tradisional menjadi tertinggal dan terdesak oleh produk olahan modern. Indonesia dikenal sebagai negara penghasil buah eksotis khas daerah tropis, seperti pisang, mangga, manggis, durian, rambutan, nanas, dan sebagainya, yang pemasaran dan ekspor sebagian besar masih berupa produk primer (raw material). Dalam tulisan ini, yang dikaji komoditi pisang dari segi produksi dan luas areal panen, yang merupakan tanaman buah-buahan yang menduduki urutan pertama di Indonesia.

Pisang (Musa paradisiaca) merupakan salah satu komoditas hortikultura unggulan nasional karena memiliki potensi karbohidrat, nutrisi, mineral dan kandungan serat serta peluang sangat tinggi sebagai bahan dan diversifikasi pangan, food security (ketahanan pangan), dan agribisnis. Pisang merupakan prioritas program pengembangan pertanian melalui penumbuhkembangan sentra produksinya. Dengan laju pertumbuhan produksi yang masih relatif rendah, sekitar 3,26 persen per tahun, yang salah satu penyebabnya diprediksi akibat terjadinya penurunan areal panen sekitar 5,72 persen per tahun, meski demikian produktivitas komoditi pisang masih mampu meningkat sekitar 8,96 persen per tahun. Terkait pengembangan program pembangunan pertanian berkelanjutan, Indonesia sudah seharusnya mengakselerasi implementasi hilirisasi melalui pengembangan agroindustri produk olahan.

Produk hortikultura bersifat musiman (seasonal), mudah rusak (perishable) sehingga harus melakukan proses pengolahan agar hasil panen bisa disimpan, dan tindakan tentunya memerlukan biaya tambahan. Proses tersebut membutuhkan peran hilirisasi agroindustri untuk menghasilkan produk olahan yang bermutu dan memiliki nilai tambah (added value). Pengembangan hilirisasi agroindustri pedesaan, penting dan strategis dalam meningkatkan pendapatan dan sekaligus membuka lapangan pekerjaan di pedesaan. Sebagai penghela pembangunan pertanian, agroindustri diharapkan mampu menciptakan pasar berbagai produk olahan berbasis pertanian, mampu memotori hilirisasi perdesaan, serta mampu menciptakan lapangan kerja dan pendapatan di perdesaan. Dengan hilirisasi agroindustri diharapkan 
terbukanya peluang usaha pengolahan produk olahan berbahan baku pisang, meningkatnya akses terhadap informasi di luar desa, dan meningkatnya pertumbuhan ekonomi.

\section{Analisis Usahatani Pisang}

Umumnya pertanaman pisang diusahakan sebagai tanaman pinggiran dan secara tumpang sari dengan kakao, kopi, dan berbagai komoditi lahan kebun lainnya. Secara umum pertanaman pisang diusahakan secara sederhana dan semi intensif. Di daerah penghasil pisang pada saat panen raya harganya sangat murah sehingga kadang-kadang karena ongkos angkutan yang lebih mahal dibandingkan dengan harga pisangnya maka buah pisang hanya dibiarkan membusuk. Varietas pisang bermacam-macam dari yang enak dimakan langsung/pisang meja (misalnya, pisang emas, pisang raja sere, pisang raja bulu, pisang ambon, pisang lampung dan lainnya) maupun yang harus diolah dulu (pisang tanduk, pisang nangka, pisang kepok, pisang uli, pisang raja bulu dan lainnya).

Tabel 1. Analisis Usahatani Pisang Tidak Intensif (Sederhana)

\begin{tabular}{lrr}
\hline & \multicolumn{2}{c}{ Usahatani Tidak Intensif } \\
\cline { 2 - 3 } Uraian & Fisik & Biaya (Rp) \\
\hline Bibit & 1.600 & 8000000 \\
Pengolahan tanah & $6 \mathrm{HOK}$ & 480000 \\
Tanam & $4 \mathrm{HOK}$ & 240000 \\
Pupuk kandang* & - & - \\
Urea* & $350 \mathrm{~kg}$ & 490000 \\
SP-36* & $150 \mathrm{~kg}$ & 390000 \\
KCl tabur* & $150 \mathrm{~kg}$ & 750000 \\
Pestisida* & $25 \mathrm{~kg}$ & 600000 \\
Penyemprotan* & - & 480000 \\
Atur anakan, penyiangan, pangkasan* & - & 480000 \\
Panen* & - & 800000 \\
Total biaya tahun I & - & 12710000 \\
Produksi tahun I & - & 18750000 \\
Pendapatan tahun I & - & 6040000 \\
Total biaya tahun ke 2 & 750 tandan & 2670000 \\
Produksi tahun ke 2 & - & 19990000 \\
Pendapatan tahun ke 2 & - & 21080000 \\
B 3 jenis mutu) & - & 0,48 \\
B/C ratio tahun I & - & 6,12 \\
B/C tahun ke 2 & &
\end{tabular}

Keterangan: * tahun ke 2

Sumber: Data Primer Diolah (Elizabeth. 2019)

$$
\text { Dengan rasanya yang enak, }
$$

kandungan gizinya tinggi terutama vitamin dan kalori, harganya murah dan mudah didapat, pisang merupakan komoditi buah-buahan yang dominan 
(sekitar $45 \%$ ) dari total konsumsi buah- buahan di Indonesia.

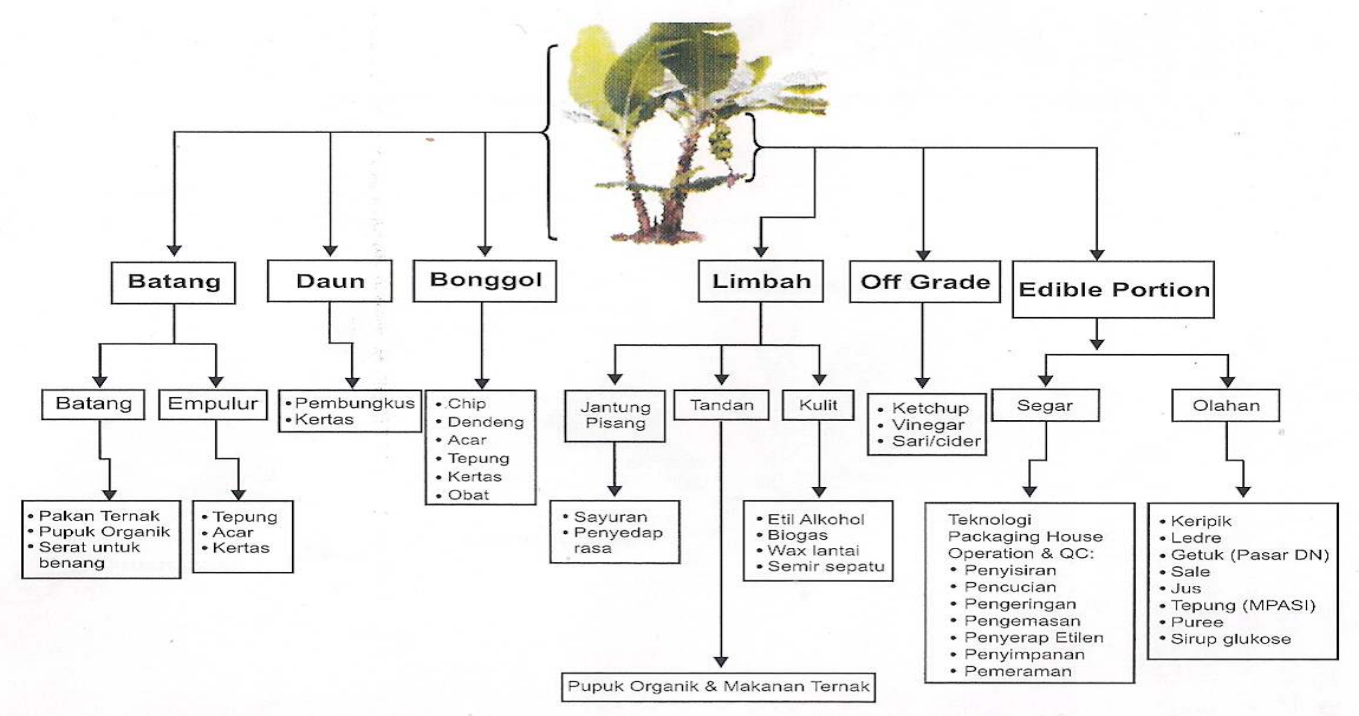

Gambar 1. Pohon Industri Pisang

\section{Agroindustri Berbasis Pisang}

Teknologi merupakan salah satu penunjang keberhasilan pengembangan hilirisasi agroindustri produk olahan, sehingga harus bersifat tepat guna, efisien, dan mudah diaplikasikan. Indonesia memiliki keragaman jenis dan teknologi pengolahan hasil produk berbahan baku pisang, namun teknik pengolahannya masih didominasi oleh cara-cara tradisional dan umumnya merupakan bagian dari kearifan lokal. Keberagaman teknologi pengolahan produk pertanian yang berkembang pada masyarakat di setiap daerah merupakan kekayaan/sumberdaya dasar (kearifan lokal) daerah tersebut. Apabila dapat diberdayakan dan didayagunakan sesuai dengan kondisi global adalah merupakan sumber kekuatan dalam pengembangan pengolahan yang memiliki nilai tambah dan berdaya saing tinggi.

Produk olahan pisang merupakan antisipasi melimpahnya produk pisang terutama saat panen raya dan mengurangi ketergantungan terhadap produk tepung sebagai substitusi tepung berbahan baku gandum (terigu), beras dan tanaman pangan lainnya. Berbagai produk olahan hasil agroindustri pisang tersebut tentu berpotensi dan berpeluang ekspor bila dikelola dengan baik dan sesuai dengan beberapa syarat-syarat yang ditetapkan sebagai produk bakal ekspor. Agroindustri pisang berpotensi menemukan peluang dalam berbagai strategi dan teknologi sebagai upaya untuk mengantisipasi limpahan pisang yang menumpuk terutama pada saat panen raya. Salah satu potensi dan peluang tersebut adalah 
pengolahan pisang menjadi berbagai produk pangan (tepung pisang, goreng pisang, kolak, keripik, stik, roll, dodol, wajik, sale, selai, aneka jenis kue seperti: biskuit, cake, bolu, dan sebagainya), minuman (jus, sirop, essence, perasa, pemanis buatan, dan sebagainya), komponen: sandang, obat-obatan, kosmetik, dan sebagainya bahkan komponen penghasil energy terbarukan (biofenery), yang merupakan produk alternatif diversifikasi komoditi pisang.

\section{a. Kelayakan Teknis}

Tekstur dan kandungan pisang memenuhi kriteria untuk diolah, yang diindikasikan dengan terdapatnya beragam hasil produk olahan pisang yang dimaknai sebagai kelayakan teknis. Kelayakan teknis tersebut diperoleh beberapa produsen pengolah pisang menjadi produk olahan, baik pada tingkat industri rumah tangga, industri sedang, maupun industri menengah dan besar. Produk olahan pisang, yang umumnya masih dalam bentuk makanan ringan (snack). Jenis pisang yang umum digunakan sebagai bahan baku produk olahan adalah hampir dari semua jenis, seperti pisang kepok putih, tanduk, nangka, ambon lumut, ambon putih, dan pisang raja bulu.
Ketersediaan dan kontiniutas bahan baku pisang yang semakin terbatas belakangan ini merupakan salah satu masalah yang umum dihadapi para pelaku pengolahan pisang, dan tentunya menjadi pertimbangan utama dan mempengaruhi pengembangan usaha pengolahan serta berkaitan erat dengan skala usaha berkelanjutan dan berkesinambungan. Pada industri pengolahan tepung pisang selain keterbatasan pasokan bahan baku pisang, permintaan yang tinggi umumnya terkendala oleh keterbatasan kapasitas olah dan jumlah mesin pengolahannya Demikian halnya dengan kecukupan ketersediaan beberapa aspek lain, seperti: bahan perasa tambahan (cita rasa dan selera konsumen), teknologi pengolahan, sumberdaya manusia sebagai pelaku/tenaga kerja pengolahan, maupun berbagai aspek terkait lainnya sebagai sarana pendukung, berperan untuk keberlangsungan dan kelancaran pemasaran hasil produk olahan pisang tersebut.

Terdapatnya beberapa pabrik/ pelaku usaha pengolah pisang, terutama industri tingkat rumah tangga dan sedang, yang menghasilkan produk tepung pisang, merupakan prospek yang memiliki potensi dan peluang tinggi 
dikemudian hari. Pada industri tingkat menengah dan besar, dihasilkan produk pisang olahan dalam bentuk tepung pisang, sebagai salah satu bahan untuk membuat bubur rasa pisang (untuk bahan baku olahan makanan bayi), dan biskuit. Prospek pabrik usaha pengolahan tepung pisang berkembang dengan adanya permintaan dari negara Singapura dan Malaysia. Dari sisi kualitas mutu, hasil produk olahan tepung pisang sangat berpotensi untuk ekspor. Dikemukakan bahwa tingginya permintaan ekspor tepung pisang tersebut, umumnya terkendala oleh keterbatasan jumlah mesin pengolahannya, dan terutama keterbatasan ketersediaan pasokan dan kontiniutas pisang sebagai bahan baku utamanya.

\section{b. Kelayakan Finansial}

Sebagai upaya peningkatan nilai tambah dan pengembangan pasar ekspor produk olahan pertanian yang berdayasaing tinggi di era globalisasi, maka Indonesia harus mengembangkan keberagaman produk olahan hasil hilirisasi agroindustri. Berbagai permasalahan yang timbul berkaitan dengan ketidakmampuan industri pengolah dalam negeri merupakan kendala serius pengembangan hilirisasi agroindustri pengolahan produk berbasis pertanian. Pengolahan pisang termasuk salah satu upaya pengembangan aneka produk olahan dan nilai tambah melalui usaha hilirisasi agroindustri produk olahan. Relatif masih kurangnya informasi dan sosialisasi kegunaan dan nilai tambah dari hasil produk olahan pisang sehingga menyebabkan belum mampu merangsang minat petani untuk mengusahakan dan memanfaatkan teknologi pengolahannya.

Tabel 2. Perkiraan Nilai Tambah Beberapa Bentuk Pengolahan Pisang

\begin{tabular}{llrr}
\hline Produk Olahan & Varietas Pisang yang Digunakan & Rendemen (\%) & Nilai Tambah \\
\hline Keripik & Ambon Hijau \& Kuning, Kepok Kuning & \pm 20 & $100-150$ \\
& \& Putih, Cavendish, dll & $17-20$ & $200-250$ \\
Ledre & Raja Bulu & $12-17$ & $100-150$ \\
Sale & Ambon, Kepok Kuning, Lampung, Mas, Uli & $20-30$ & $50-100$ \\
Getuk & Nangka & $50-60$ & $350-500$ \\
Jus & Raja Bulu & $29-32$ & $350-450$ \\
Tepung & Siem, Nangka, Kepok & $9-11,5$ & $600-650$ \\
Tepung MPASI & Ambon & $20-30$ & $150-200$ \\
Puree & Ambon, Cavendish dan Raja Bulu & $70-75$ & $200-500$ \\
Jam/selai & Ambon, Cavendish dan Raja Bulu & &
\end{tabular}




\section{AKSELERASI HILIRISASI PRODUK AGROINDUSTRI BERDAYASAING MENDONGKRAK \\ KESEJAHTERAAN PETANI DAN EKONOMI PEDESAAN \\ Roosganda Elizabeth, Iwan Setiajie Anugrah}

Tabel 3 sebagai contoh analisis rincian biaya usaha membuat keripik nilai tambah, berikut dikemukakan pisang per satu kali produksi:

Tabel 3. Analisa Usaha Agroindustri Keripik Pisang (berbagai rasa)

\begin{tabular}{|c|c|}
\hline Uraian & Harga $(\mathrm{Rp})$ \\
\hline 1. a. Nilai bahan baku pisang nangka: $100 \mathrm{~kg}$ x Rp. $3000,-$ & 300.000 \\
\hline b. bumbu perasa (pizza, keju, BBQ, coklat, gula, royco) & 100.000 \\
\hline c. gas (bahan bakar) & 15.000 \\
\hline d. minyak goreng =10 lt @ Rp.12000 & 120.000 \\
\hline e. plastik kemasan bermerek nama usaha & 20.000 \\
\hline f. Biaya TK 2 orang@ Rp.50000/hari (1 hari jadi) & 100.000 \\
\hline g. Biaya transportasi pemasaran & 36.000 \\
\hline Total Biaya Bahan Baku & 571.000 \\
\hline \multicolumn{2}{|l|}{ 2. Nilai pendapatan produk olahan (keripik pisang): } \\
\hline \multicolumn{2}{|l|}{$30 \mathrm{~kg}$ keripik pisang berbagai rasa: } \\
\hline -. Rasa coklat, keju, BBQ, pizza, pedas=25 kg@Rp.45000/kg & 1.125 .000 \\
\hline -. Rasa original asin, manis = 5 kg@ Rp.40000/kg & 200.000 \\
\hline Total Pendapatan Keripik Pisang & 1.325 .000 \\
\hline Keuntungan per $1 \mathrm{x}$ produksi, sekitar & 754.000 \\
\hline
\end{tabular}

Produk pisang olahan tingkat industri rumahtangga dan menengah yang sudah berjalan adalah dalam bentuk makanan ringan (snack) dan aneka kue/bolu, dodol dan wajik. Keripik pisang yang diproduksi berbahan baku pisang nangka. Rendemen yang diperoleh dari 1 kuintal bahan baku pisang adalah sekitar 30\%-35\% keripik pisang. Dari Tabel 3 diketahui hasil analisis nilai tambah usaha produk olahan keripik pisang diperoleh keuntungan sekitar Rp 754.000 per satu kali produksi, dengan $\mathrm{B} / \mathrm{C}$ ratio 1,32 . Dari hasil analisis nilai tambah usaha produk olahan sale pisang diperoleh keuntungan sekitar $\mathrm{Rp}$ 5.380.000 per satu kali produksi, dengan $\mathrm{B} / \mathrm{C}$ ratio 1,97. Keuntungan tersebut biasanya bertambah pada proses produksi berikutnya karena beberapa bahan penunjang, misalnya: bahan perasa, minyak goreng dan plastik kemasan dapat digunakan untuk 2-4 kali produksi. Pada pembuatan sale pisang (sale basah dan goreng), rendemen yang diperoleh dari 1 kuintal bahan baku pisang menjadi sekitar 30\% - 45\% kg sale pisang kering jemur (sekitar 2-3 hari bila sinar matahari cukup). Berikut dikemukakan secara sederhana analisis usaha produksi sale pisang untuk satu kali kegiatan produksi. Untuk $3 \mathrm{kw}$ sale pisang yang dihasilkan dijual dengan harga $\mathrm{Rp}$ 40.000-Rp 45.000 per $\mathrm{kg}$.

Sebagai suatu investasi, usaha pengolahan tentu berkaitan dengan analisis finansial (ekonomi) untuk mendasari pertimbangan kelayakan suatu usaha produk olahan yang dihasilkan dari aspek financial, yang berkaitan dengan 
manfaat investasi bagi daerah usaha tersebut beraktivitas. Pertimbangan kelayakan finansial tersebut juga meliputi perolehan pendapatan yang diperoleh para tenaga kerja, pemasok bahan baku dan petani produsen pisang, serta sarana transportasi untuk pengangkutan pasokan bahan baku maupun pemasaran hasil produk olahan. Manfaat kelayakan financial dari kegiatan investasi suatu usaha pengolahan bagi wilayah keseluruhan usaha pengolahan tersebut beraktivitas tentu sangat diharapkan baik oleh pemerintah daerah, terutama oleh masyarakat di sekitar lokasi perusahaan pengolah tersebut. Kelayakan finansial tersebut diharapkan memberikan keuntungan mencakup wilayah yang terkait usaha pengolahan suatu produk secara menyeluruh dari hulu (produsen bahan baku/petani pisang, pengumpul) sampai ke hilir (produk olahan, distributor dan pemasaran). Pertimbangan kelayakan finansial tersebut juga meliputi perolehan pendapatan yang diperoleh para tenaga kerja, pemasok bahan baku dan petani produsen pisang, serta sarana transportasi untuk pengangkutan pasokan bahan baku maupun pemasaran hasil produk olahan.

Tabel 4. Analisa Usaha Agroindustri Sale Pisang

\begin{tabular}{|c|c|}
\hline Uraian & $\mathrm{Rp}$ \\
\hline 300 kg pisang@Rp 3000 & 900.000 \\
\hline \multicolumn{2}{|l|}{ Bahan-bahan penunjang produksi yang dibutuhkan, meliputi: } \\
\hline 8 kg@Rp. 6000/kg & 48.000 \\
\hline 25 kg@Rp.10000/kg & 250.000 \\
\hline 4 kg@Rp. 8000/kg & 32.000 \\
\hline -. Minyak goreng (Bimoli) & 360.000 \\
\hline -. Plastik & 50.000 \\
\hline $\begin{array}{l}\text {-. Upah tenaga kerja: } 2 \text { orang @ Rp. 100000/orang } \\
\text { (penggorengan,penjemuran, pengemasan) }\end{array}$ & 200.000 \\
\hline Total Biaya & 1.820 .000 \\
\hline Pendapatan: 45 kg sale basah@ @ Rp.40000 & 1.800 .000 \\
\hline 80 kg sale kering@Rp.45000 & 3.600 .000 \\
\hline Total Pendapatan & 5.400 .000 \\
\hline Keuntungan per satu kali produksi & 3.580 .000 \\
\hline
\end{tabular}

\section{c. Kelayakan Sosial dan Lingkungan}

Faktor sosial dan lingkungan merupakan salah satu aspek yang mempengaruhi kelangsungan dan kesinambungan suatu usaha pengolahan produk dalam jangka panjang (berkelanjutan). Beberapa upaya yang dilakukan, seperti: (i) menggunakan tenaga kerja dari lingkungan sekitar tempat usaha pengolahan tersebut beraktivitas; (ii) turut serta berperan dalam beberapa kegiatan sosial di 


\section{AKSELERASI HILIRISASI PRODUK AGROINDUSTRI BERDAYASAING MENDONGKRAK \\ KESEJAHTERAAN PETANI DAN EKONOMI PEDESAAN \\ Roosganda Elizabeth, Iwan Setiajie Anugrah}

lingkungan tempat usaha terutama aktivitas sosial yang terkait dengan kelangsungan usaha tersebut; (iii) mengadakan pelatihan pengolahan produk bagi masyarakat di lingkungan tempat usaha maupun masyarakat pendatang dari luar daerah yang membutuhkan pelatihan tersebut; (iv) secara berkala mensosialisasikan aktivitas dan produk olahan hasil tempat usaha dan kegiatan yang rutin dilakukan para tenaga kerja dan pelaku produksi di tempat usaha turut, serta menjaga dan memelihara kebersihan serta kelestarian lingkungan tempat usaha pengolahan tersebut berada.

Selain itu, hasil sampingan agroindustri pisang menjadi pupuk organik mengindikasikan terdapatnya kelayakan lingkungan, dengan berperannya upaya pelestarian lingkungan. Hal tersebut dikaji dari pemanfaatan kulit buah pisang (sisa-sisa bahan baku utama dari buah pisang) yang diolah menjadi pupuk organik. Pupuk organik yang bermanfaat untuk menyuburkan tanah dan tanaman yang ramah lingkungan, serta berperan untuk mengurangi pemakaian pupuk anorganik. Dalam pembuatan pupuk organik tersebut, tentunya membutuhkan tenagakerja dari lingkungan sekitar pabrik, yang mengindikasikan bahwa secara kelayakan sosial, perusahaan tersebut telah memperkerjakan tenaga kerja yang berada di lingkungan perusahaan.

\section{d. Dukungan Infrastruktur}

Suatu usaha pengolahan dapat menghasilkan produk hasil olahan bila didukung tersedianya dan berfungsinya berbagai peralatan pengolahan, baik dimulai dari pengadaan bahan baku, proses pengolahan produk, pengemasan, dan sebagainya hingga proses pendistribusian dan pemasaran hasil produksi pengolahan produk bisa diperoleh konsumen, sebagai duungan infrastruktur. Ketersediaan berbagai peralatan yang lebih modern dan higyenis untuk proses pembuatan produk olahan, merupakan syarat pendukung utama untuk kelancaran dan kesinambungan suatu usaha produk olahan. Ketersediaan berbagai sarana dan prasarana infrastruktur sebagai akses pendukung termasuk sarana dan prasarana transportasi yang terkait merupakan faktor-faktor pendukung kelancaran dan berlangsungnya aktivitas suatu usaha pengolahan produk.

\section{e. Dukungan Kebijakan}

Dukungan kebijakan yang terutama tercantum dalam berbagai program 
kebijakan pembangunan dan pengembangan pertanian dan agribisnis di pedesaan. Kebijakan tersebut juga berkaitan erat dengan kebijakan pemerintah dalam rangka mendukung program ketahanan pangan, peningkatan pendapatan dan pensejahteraan petani dan pedesaan. Kebijakan pengembangan pisang dimulai dari melakukan registrasi ulang di sentra produksi, baik lahan pertanaman (areal tanam dan panen), pengembangan pengelolaan budidaya, maupun pengolahan hasil dan peluangnya. Pengolahan produk berbahan baku pisang dilaksanakan secara sinergis dengan beberapa pihak terkait selain Dinas Pertanian, seperti: Dinas Koperasi, Perdagangan dan Perindustrian, dll. Terdapatnya kebijakan pengembangan pengolahan produk berbahan baku pisang yang diarahkan ke produk tepung pisang. Adanya pemberian bantuan baik dari pemerintah maupun swasta merupakan dukungan bagi pengembangan pengolahan produk. Bantuan tersebut dapat berupa program bantuan permodalan (kredit lunak), bantuan peralatan/ mesin pengolahan maupun dalam bentuk pelatihan dan pendidikan teknologi pengolahan dan strategi pemasaran.

\section{Terciptanya Nilai Tambah Dari Produk Olahan Pisang}

Untuk mengatasi kerusakan dan meningkatkan nilai harga maka dilakukan dengan memproses buah pisang menjadi bahan olahan jadi (keripik, dodol, selai, sale, tape, getuk, pasta, esen/perasa, dan lainnya) maupun olahan setengah jadi (tepung pisang dan gaplek pisang).

\section{Keripik pisang}

Dari hasil analisa usahatani teknologi pengolahan keripik pisang dapat dilihat bahwa tingkat keuntungan yang diperoleh cukup tinggi, dimana B/C Ratio lebih dari 1 yaitu 2,07. Dengan demikian teknologi pengolahan keripik pisang layak untuk diusahakan. Hasil analisa usahatani keripik pisang dapat dilihat pada Tabel 4.

Dengan mencermati perbandingan pendapatan dan $\mathrm{B} / \mathrm{C}$ ratio antara komoditi dengan produk olahan pisang, tercermin pertambahan pendapatan yang signifikan dari produk olahan pisang, meski bahan baku pisang diperoleh dari pasar, tanpa menanam sendiri, apalagi bila dilakukan oleh petani pisang dengan melakukan proses pengolahan dari pisang diperoleh dari usahatani sendiri. Kajian ini diharapkan dapat meningkatkan minat dan semangat para pelaku usaha pisang, mulai dari usahatani (hulu) hingga 


\section{AKSELERASI HILIRISASI PRODUK AGROINDUSTRI BERDAYASAING MENDONGKRAK KESEJAHTERAAN PETANI DAN EKONOMI PEDESAAN \\ Roosganda Elizabeth, Iwan Setiajie Anugrah}

menjadi produk olahan (hilir) dalam pisang.

mengembangkan hilirisasi agroindustri

Tabel 5. Hasil Analisa Usahatani Keripik Pisang

1. Biaya produksi

a. Alat/sarana

\begin{tabular}{lcccc}
\hline \multicolumn{1}{c}{ Jenis alat } & Jumlah (buah) & Nilai (Rp) & Umur pakai alat (bln) & Penyusutan (Rp) \\
\hline Toples besar & 2 & 50.000 & 2 & 8.000 \\
Kompor + tabung & 1 & 700.000 & 24 & 29.000 \\
Wajan & 1 & 150.000 & 6 & 25.000 \\
Sotil & 2 & 50.000 & 6 & 8.000 \\
Pisau & 2 & 30.000 & 6 & 6.000 \\
Serok & 2 & 50.000 & 6 & 8.000
\end{tabular}

\begin{tabular}{lcccc}
\hline \multicolumn{1}{r}{ Jenis alat } & Jumlah (buah) & Nilai (Rp) & Umur pakai (bln) & Penyusutan (Rp) \\
\hline Baskom plastik & 2 & 30.000 & 6 & 6.000 \\
Siler & 1 & 500.000 & 12 & 41.000 \\
Pengiris pisang & 2 & 50.000 & 6 & 8.000 \\
\hline \multicolumn{2}{r}{ Total Biaya Alat } & 139.000 \\
\hline
\end{tabular}

b. Bahan

\begin{tabular}{|c|c|c|c|}
\hline Jenis bahan & Volume & Harga satuan & Jumlah (Rp) \\
\hline \multicolumn{4}{|l|}{ Bahan utama } \\
\hline Pisang tua mentah & 450 sisir & 5,000 & $2,250,000$ \\
\hline Minyak goreng & 120 liter & 12,000 & $1,440,000$ \\
\hline Bumbu & $30 \mathrm{bks}$ & 10,000 & 300,000 \\
\hline Garam & $30 \mathrm{bks}$ & 2,500 & 75,000 \\
\hline \multicolumn{4}{|l|}{ Bahan penunjang } \\
\hline Gas & $5 \mathrm{tbg}$ & 150.000 & 750,000 \\
\hline \multirow[t]{2}{*}{ Plastik } & 2 gulung & 50,000 & 100,000 \\
\hline & & Jumlah & 4.915 .000 \\
\hline \multicolumn{4}{|l|}{ Lain-lain } \\
\hline Upah tenaga & 30 hari & 50,000 & $1,500,000$ \\
\hline Transportasi & 30 hari & 10.000 & 300,000 \\
\hline Sewa tempat & 1 bulan & 300,000 & 300,000 \\
\hline \multirow[t]{3}{*}{$\underline{\text { Listrik }}$} & 30 hari & 3000 & 90,000 \\
\hline & & Jumlah & $2,190,000$ \\
\hline & aya & & Rp 7244000 \\
\hline \multicolumn{2}{|c|}{ Hasil penjualan 3.000 bks @ Rp. 5.000} & & Rp 15000000 \\
\hline \multicolumn{2}{|c|}{ Keuntungan $(2-1)=(15.000 .000-7.244 .000)$} & & $\mathrm{Rp} \quad 7776000$ \\
\hline & & & 2,07 \\
\hline
\end{tabular}

Sumber: beberapa literatur, dianalisis sesuai tujuan tulisan dalam Elizabeth, 2019

\section{f. Potensi pemasaran produk pisang}

Dari rata-rata produksi 530.667 ton/tahun dipasarkan untuk Jabodetabek dan lokal dengan harga pisang segar Rp
$1.600 / \mathrm{kg}$, maka nilai perdagangan pisang segar mencapai sekitar $\mathrm{Rp} \quad 717,867$ milyar. Bila harga keripik pisang sekitar $\mathrm{Rp} 12.000 / \mathrm{kg}$, maka nilai perdagangan 
pisang olahan (keripik pisang) mencapai sekitar: Rp 50,4 milyar (0,6 x 7.000 x Rp 12.000/kg). Pengembangan industri pisang olahan akan terus meningkat sejalan dengan meningkatnya dinamika pasar domestik dan ekspor.

\section{Potensi pemasaran Internasional Pisang Olahan}

Dalam direktori yang dikeluarkan Disperindag Prov. Lampung, produk pisang olahan digabungkan dalam kelompok keripik pisang/nangka, diketahui bahwa pada tahun 2004 saja Prov. Lampung pernah mengekspor keripik pisang/nangka dengan volume senilai US \$ 26.402, atau sekitar 0,005 persen dari volume ekspor hasil industri sekitar 1,6 juta ton atau senilai US \$ 593,27 juta. Namun, untuk tahun-tahun berikutnya, prov. Lampung tidak pernah mengekspor pisang olahan lagi. Lampung pernah melakukan ekspor keripik pisang sejumlah 9,54 ton sekitar lima tahun sebelumnya. Dengan proyeksi berikut, adalah sangat memungkinkan merencanakan ekspor pisang olahan pada tahuntahun mendatang.

Untuk itu, haruslah juga mempertimbangkan kondisi dan perkembangan krisis ekonomi global, yang menyebabkan merosotnya permintaan pasar luar negeri. Tetapi, bila disiasati dengan baik, bijak dan berpihak, akan membuka luas peluang pasar ekspor untuk produk pisang olahan. Penumbuhan kelembagaan kelompok petani pisang tersebut hendaknya mengikuti beberapa tahapan dan prinsipprinsip, seperti: kebebasan (menghargai), keterbukaan, partisipatif, keswadayaan, kesetaraan, dan kemitraan (partnership). Denan demikian, kelembagaan kelompok petani yang kelak terbentuk, dapat difungsikan sebagai: kelas belajar, wahana kerjasama, dan unit produksi.

\section{g. Dukungan Kebijakan}

Seiring arah pengembangan pisang, terutama ekstensifikasinya secara nasional, meski tidak lagi diarahkan ke Lampung, tetapi ke daerah lain: Kalimantan Selatan, Kalimantan Timur, Maluku dan Papua, namun terbukti dari tahun ke tahun bahwa Lampung selalu surplus dalam produksi pisang, sehingga masih sangat potensial sebagai komoditas unggulan daerah. Lampung juga telah mengekspor pisang ke China, Hongkong, Iran, Jepang, Kore, Kuwait, Malaysia, Singapura, Saudi Arabia dan Uni Emirat Arab.Membanjirnya produk luar negeri perlu segera dihadapi dengan meningkatkan dayasaing produk domestik; yang dilakukan melalui perbaikan mutu dan effisiensi produk, 


\section{AKSELERASI HILIRISASI PRODUK AGROINDUSTRI BERDAYASAING MENDONGKRAK \\ KESEJAHTERAAN PETANI DAN EKONOMI PEDESAAN \\ Roosganda Elizabeth, Iwan Setiajie Anugrah}

serta diikuti oleh meningkatkan rasa bangga dan kecintaan terhadap produk nasional. Untuk melindungi sektor pertanian dari persaingan di pasar dunia dalam rangka mendukung keberhasilan produk olahan hasil agroindustri diperlukan beberapa kebijakan.

Dalam rangka keberhasilan program pembangunan pertanian yang berkelanjutan melalui akselerasi hilirisasi agroindustri untuk memperkuat pengembangan hasil usaha pengolahan pisang, sangat dibutuhkan dukungan kebijakan eksekutif dan legislatif tingkat provinsi maupun kabupaten/kota. Kebijakan pemerintah yang umumnya bias investasi fisik dan permodalan akan lebih bermanfaat bila diselaraskan dengan pengembangan kelembagaan perdesaan yang identik dengan perkembangan pertanian, sehingga diharapkan mampu mengakomodasi pengembangan agroindustri berbasis produk pertanian. Pengembangan agroindustri bahan pangan di perdesaan perlu disertai oleh program yang langsung menuju ke sasaran (rumah tangga petani sebagai subjek), dimana agroindustri dikombinasikan dengan rural development sehingga menjadi satu program pembangunan perdesaan komprehensif. Diharapkan dengan sentuhan inovasi teknologi, pembinaan dan pemberdayaan SDM di perdesaan mampu mengembangkan produk olahan bernilai kompetitif dan disukai oleh konsumen, dengan demikian secara tidak langsung dapat menciptakan peluang kerja dan peluang pasar. Untuk itu, sistem agroindustri komoditas pertanian diarahkan untuk mewujudkan sistem pertanian industrial berdayasaing, berkeadilan dan berkelanjutan guna menjamin ketahanan pangan dan kesejahteraan masyarakat pertanian.

Berdasarkan Permentan No 35/Permentan/OT.140/7/2008 tentang Pengolahan hasil pertanian asal tumbuhan adalah mengubah bahan baku menjadi produk primer, setengah jadi atau produk jadi, yang bertujuan: untuk meningkatkan daya simpan ataupun meningkatkan nilai tambah hasil pertanian; serta meminimalisir kerugian karena nilai tambah produk tersebut diambil alih negara lain. Lahirnya UU No.13 Tahun 2014 Tentang Perindustrian, beberapa pertimbangan mengenai perlu dan pentingnya pelaksanaan kegiatan usaha produk olahan berbasis hasil pertanian dan pengembangannya (Bappenas, 2013; Balai Besar Industri Agro Bogor (BBIA Bogor, 2014; Bappenas, 2015; Rafki, 
2015), antara lain: (i) sumberdaya alam Indonesia yang kaya dan menyebar rata di seluruh penjuru tanah air, sehingga perlu mendorong usaha industri produk olahan; (ii) penciptaan kesempatan kerja seluas-luasnya; (iii) meningkatkan nilai tambah (value added); (iv) peningkatan pendapatan yang terkait dengan kesejahteraan pelaku usahatani; (v) membuka peluang ekspor; dan (vi) diyakini akan berdampak dan menciptakan pemerataan pembangunan. Peraturan tersebut hendaknya dimaknai sebagai suatu penegasan bahwa sistem industri nasional secara substantif telah memberikan arah pengaturan yang benar tentang pentingnya pembangunan sektor industri berbasis sumberdaya alam.

Berbagai kebijakan tersebut, didasari oleh: (1) Pengembangan standarisasi mutu hasil pisang olahan yang berlaku pada usaha menengah, kecil, maupun mikro (semua skala usaha); (2) Pengembangan kelembagaan pelaku usaha, misalnya Asosiasi Pengusaha Pisang (APP); (3) Pengembangan dan pengelolaan potensi pasar domestik pisang segar, dengan membangun terminal hortikultura (khususnya pisang), sehingga membuka peluang penyerapan lapangan kerja, pengefisiensien waktu angkut, dan penyediaan pasokan dan kontiniutas bahan baku pisang segar dengan meminimalkan limbahnya; (4) Penggunaan berbagai peralatan berteknologi yang lebih maju dalam pengelolaan dan pengolahan bahan baku pisang segar, misalnya controlled atmosphere storage, vacum frying, dan modified atmosphere packaging; (5) Pisang olahan dalam bentuk tepung pisang dan pure pisang sangat potensial untuk dikembangkan; (6) Pengelolaan dan pengolahan limbah kulit pisang dan dimanfaatkan sebagai pupuk organik, vinegar dan bahan bakar metan serta bioetanol yang sangat potensial dikembangkan; (7) Pembatasan impor pisang segar melalui persyaratan yang cukup ketat, sehingga akan mengurangi persaingan harga dengan produk luar negeri dan meningkatkan motivasi investor lokal untuk agribisnis pisang; (8) Regulasi yang mengharuskan pasar-pasar swalayan dan modern untuk menampilkan buah pisang lokal yang bermutu berdampingan/sejajar dengan pisang impor; (9) Memperlancar dan mempermudah akses sumber permodalan dengan bunga lunak; (10) Perluasan pasar ekspor untuk tujuan negara-negara nondolar yang didukung penuh dengan kemudahan di bidang transportasi, perizinan, dan bidang terkait lainnya, 


\section{AKSELERASI HILIRISASI PRODUK AGROINDUSTRI BERDAYASAING MENDONGKRAK \\ KESEJAHTERAAN PETANI DAN EKONOMI PEDESAAN \\ Roosganda Elizabeth, Iwan Setiajie Anugrah}

khususnya tarif angkutan udara mendukung ekspor pisang; (11) Jaminan keamanan berinvestasi yang berpihak di lokasi usaha.

Oleh karena itu, sistem agroindustri komoditas pertanian diarahkan untuk mewujudkan sistem pertanian industrial berdayasaing, berkeadilan dan berkelanjutan guna menjamin ketahanan pangan dan kesejahteraan masyarakat pertanian. Hal tersebut membutuhkan beberapa dukungan kebijakan terkait lainnya, yaitu: (a) Pembangunan infrastruktur pertanian, meliputi pembangunan dan rehabilitasi jaringan irigasi, perluasan lahan pertanian, terutama di luar Jawa, pencegahan konversi lahan terutama di Jawa, pengembangan jalan usahatani dan jalan produksi serta infrastruktur lainnya; (b) Kebijakan pembiayaan untuk mengembangkan lembaga keuangan yang khusus melayani sektor pertanian, lembaga keuangan mikro, pembiayaan pola syaraiah, dan lainnya; (c) Kebijakan ekonomi makro yang kondusif, yaitu inflasi yang rendah, nilai tukar yang stabil dan suku bunga riil positif; (d) Kebijakan perdagangan yang memfasilitasi kelancaran pemasaran, baik di pasar dalam negeri maupun ekspor; (e) Kebijakan pengembangan industri yang lebih menekankan pada agroindustri skala kecil di perdesaan dalam rangka meningkatkan nilai tambah dan pendapatan petani; (f) Kebijakan investasi yang kondusif untuk lebih mendorong minat investor dalam sektor pertanian; (g) Pembiayaan pembangunan yang lebih memprioritaskan anggaran untuk sektor pertanian dan sektor-sektor pendukungnya; (h) Perhatian pemerintah daerah pada pembangunan pertanian meliputi: infrastuktur pertanian, pemberdayaan penyuluh pertanian, pengembangan instansi lingkup pertanian, menghilangkan berbagai pungutan yang mengurangi dayasaing pertanian, serta alokasi APBD yang memadai. Dengan demikian, keberhasilan pelaksanaan program/kegiatan dalam pencapaian tujuan dan sasaran yang telah ditetapkan melibatkan aspek yang sangat luas dan terkait melalui kerjasama yang harmonis, efektif, dan saling mendukung dengan kewenangan di dalam dan di luar satuan kerja yang membidangi pertanian tanaman hortikultura bersama seluruh lintas pemangku kepentingan harus diwujudkan secara intensif dan berkelanjutan. 


\section{PROSPEK \\ DAN \\ PENGEMBANGAN \\ AGROINDUSTRI \\ PEMBERDAYAAN KELEMBAGA- AN DAN SDM PERTANIAN}

Akselerasi hilirisasi agroindustri komoditas pertanian juga diartikan sebagai usaha, proses dan program kebijakan untuk menyegarkan kembali pertanian multi guna, memberdayakan kemampuannya, membangun dayasaingnya, meningkatkan kinerjanya, serta mensejahterakan pelakunya, terutama petani, sebagai bagian dari usaha untuk mensejahterakan seluruh rakyat. Akselerasi hilirisasi yang ditempuh dengan menumbuhkembangkan dan meningkatkan kegiatan agroindustri untuk memperkuat proses pengolahan produk, sertapengembangan teknologi di sektor industri pengolahan, akan memperkuat posisi tawar berbagai produk olahan berbasis pertanian Indonesia, baik di pasar regional maupun di pasar dunia (internasional). Implementasi dan akselerasi pengembangan dan peningkatan kegiatan hilirisasi agroindustri membuat bangsa Indonesia bisa melepaskan diri dari jebakan paradox of plenty, yaitu sebuah kondisi dimana suatu negara yang kaya sumberdaya alam tetapi rakyatnya miskin (Fauzi, 2014). Hilirisasi agroindustri juga memiliki keterkaitan: konsumsi, investasi, dan tenaga kerja (John and Rocha, 2009; Ronald dan Peter, 2009), yang menyebabkan terjadinya relokasi sumberdaya (SDM dan modal) antar sektor, sehingga ada sektor lain yang dikorbankan dalam proses dari produk primer ke produk hasil olahan (Elizabeth, 2017; 2017a).

Untuk meningkatkan dayasaing produk perdagangan Indonesia, keragaman teknologi pengolahan produk pertanian domestik di setiap daerah harus dapat didayagunakan dan disesuaikan dengan kondisi global sebagai sumber kekuatan dalam pengembangan produk agroindustri yang berdayasaing. Dalam upaya pengembangan dan peningkatan produk olahan agroindustri yang berdayasaing, dibutuhkan peningkatan effisiensi dan mutu produk melalui perbaikan sistem produksi, pasca panen dan pengolahan (GAP dan GMP). Globalisasi perdagangan meliputi berbagai tantangan yang bervariasi yang hendaknya dimaknai sebagai peluang bagi produk olahan Indonesia untuk dapat bersaing di pasar internasional mencakup: (i) kokohnya pasar domestik produk, supaya tidak hanya dibanjiri produk impor; (ii) penyediaan produk yang aman, higienis, berkualitas tinggi dan terjamin dan harga bersaing; (iii) 


\section{AKSELERASI HILIRISASI PRODUK AGROINDUSTRI BERDAYASAING MENDONGKRAK \\ KESEJAHTERAAN PETANI DAN EKONOMI PEDESAAN \\ Roosganda Elizabeth, Iwan Setiajie Anugrah}

kontiniutas penyediaan produk dan memadainya dukungan kondisi dan sarana lingkungan (Elizabeth, 2015).

Strategi tersebut merupakan sebuah resultante penyikapan secara cerdas bahwa cara pengelolaan SDA harus ditingkatkan dan dikembangkan, sehingga diperlukan implementasi dan akselerasi revitalisasi kegiatan agroindustri (Hadi, 2014; Elizabeth, 2017; 2018a). Agroindustri juga memiliki keterkaitan kuat antar sektor yang tidak hanya keterkaitan produk, tetapi juga melalui keterkaitan konsumsi, investasi, dan tenagakerja. Keterkaitan tersebut karena tenagakerja dan modalnya direalokasikan ke proses pengolahan (dari produk primer menjadi produk olahan) yang dilengkapi analisa kelayakan usaha; yang meliputi: keragaan umum, kelayakan finansial, kelayakan ekonomi, kelayakan sosial dan lingkungan, kelayakan teknis, dukungan infrastruktur; dan kebijakan, sebagai data dukung (Rachmat et al, 2012 dalam Elizabeth, 2018, 2018a).

Pengembangan produk olahan mempunyai berbagai keuntungan ganda (multi utility), seperti: (i) sebagai promosi ekspor dan sekaligus substitusi impor; (ii) menciptakan nilai tambah pertanian; (iii) menciptakan lapangan kerja industri; dan (iv) meningkatnya adopsi teknologi. Bila kondisi tersebut dilaksanakan dengan baik, maka: 1) peluang pasar global dapat didayagunakan; (2) diperolehnya nilai tambah (Kaniasari, 2012; Kusuwardhani, 2012); dan berarti pula akan (3) mengurangi impor produk olahan. Pengembangan agroindustri bertujuan supaya mampu menghasilkan beragam produk olahan yang berdayasaing tinggi terutama di era globalisasi perdagangan saat ini. Penerapan inovasi teknologi agroindustri di perdesaan diupayakan memiliki kredibilitas, bisa memberi inspirasi semangat kerja untuk maju, serta kondisi masing-masing daerah (spesifik lokasi) perlu dipertimbangkan dan di jadikan dasar perancangan pengembangan agroindustri di perdesaan. Program pengembangan teknologi dan investasi di perdesaan akan mampu menjadi "mesin penggerak" kemajuan ekonomi yang tangguh, jika sistem kelembagaannya berfungsi sejalan dengan program pembangunan yang dilaksanakan. Pengembangan teknologi penanganan dan pengolahan produk agroindustri merupakan salah satu faktor penunjang pengembangan dan peningkatan sistem agroindustri di perdesaan (Hermanto, 2015; Hermen, 2015; Elizabeth, 2016). Hal tersebut 
terkait erat dengan pengembangan kelembagaan SDM pelaku pengusahaannya dan berbagai kelembagaan terkait lainnya.

Terkait dengan hal tersebut, peningkatan nilai tambah produk pertanian merupakan salah satu target utama Kementerian Pertanian dalam rangka pengembangan industri hilir pertanian. Kebijakan tersebut dilaksanakan antara lain melalui peningkatan produk olahan yang diperdagangkan, pengembangan dan peningkatan produk olahan berbasis hasil pertanian dan bertujuan ekspor untuk memperoleh peningkatan surplus perdagangan luar negeri. Implementasi akselerasi agroindustri dan tercapainya nilai tambah produk olahan, dapat mendukung pencapaian dayasaing produk dan percepatan pembangunan pertanian di Indonesia (Elizabeth, 2018). Dengan demikian, usaha agroindustri dapat dijadikan sebagai sumber pendapatan sebagian besar penduduk (seiring dengan berkembangnya sektor pertanian primer, sebagai lapangan pekerjaan dan tempat berusaha, yang diharapkan dapat meningkatkan perolehan pendapatan dan mewujudkan kesejahteraan petani.

Di era globalisasi sekarang ini, kondisi agroindustri masih dilatar belakangi masalah relatif belum pengalaman. Untuk memasuki ranah ekspor, diperlukan pemahaman seluk beluk dan ketrampilan serta keahlian khusus serta membutuhkan dukungan modal dan sistem pengelolaan yang handal. Meski demikian, diperoleh informasi bahwa upaya pengolahan produk pisang meningkat sekitar 1 persen setiap tahunnya. Indonesia masih mengimpor produk olahan, baik untuk komoditi pangan, hortikultura, perkebunan dan peternakan. Kondisi tersebut tentu sangat merugikan karena harga bahan baku rendah sementara harga produk olahan yang diimpor jauh lebih mahal, serta mengakibatkan hilangnya nilai tambah produk pertanian tersebut.

Kebijakan pembangunan dan pengembangan agroindustri terutama untuk mendorong terciptanya keseimbangan struktur perekonomian, sebagai penghela pembangunan sektor pertanian. Beberapa sasarannya adalah terciptanya nilai tambah (value added) (Bahtiar dan Kindangen, 2011) dan lapangan kerja, peningkatan pembagian dan penyebaran pendapatan, penyerapan dan produktivitas kelembagaan seperti tenaga kerja dan pasar sehingga mampu meraih dan memperluas jangkauan pemasaran, serta peningkatan penerimaan devisa. 


\section{AKSELERASI HILIRISASI PRODUK AGROINDUSTRI BERDAYASAING MENDONGKRAK \\ KESEJAHTERAAN PETANI DAN EKONOMI PEDESAAN \\ Roosganda Elizabeth, Iwan Setiajie Anugrah}

Pemanfaatan untuk kepentingan sepihak terhadap potensi utama sumberdaya ekonomi perdesaan (lokal) mengakibatkan terbengkalainya kelembagaan pertanian yang justru menghambat keberhasilan pembangunan pertanian perdesaan. Implementasi, aplikasi, dan pengembangan jejaring sosial sektor pertanian di perdesaan dapat dilakukan melalui pemberdayaan dan penguatan kelembagaan pertanian serta berfungsi sebagai wadah, rantai alur dan alir perekonomian di perdesaan. Apabila sistem kelembagaan tidak berfungsi, maka program pengembangan teknologi dan investasi tidak akan mampu menjadi "mesin penggerak" kemajuan ekonomi yang tangguh (Elizabeth, 2008).

Untuk itu dibutuhkan upaya memperkuat jaringan sosial masyarakat dan kelembagaan untuk menumbuhkan perekonomian perdesaan baik dari aspek struktur atau konfigurasinya (sebagai jaringan yang efisien), keanggotaan (tingkat partisipasi masyarakat), maupun peranan atau fungsi (pembagian kerja secara organik). Kelembagaan pertanian dan perdesaan perlu bersinergis agar sesuai dengan kebutuhan, pemberdayaan kelembagaan, yang dilakukan secara internal dan eksternal dari keseluruhan kelembagaan tersebut. Sistem kelemba- gaan suatu masyarakat yang rapuh melemahkan keberhasilan implementasi program pembangunan pertanian, termasuk pengembangan teknologi, inovasi dan investasi, serta tidak tercapainya kemajuan ekonomi yang tangguh (Elizabeth, 2016; 2018). Pemahaman konsep pemberdayaan kelembagaan pertanian, termasuk lembaga tenagakerja, modal dan pemasaran, menjadi landasan pemikiran dalam mengkaji dan mengurai berbagai kendala dan pencapaian sasaran untuk terciptanya struktur perekonomian yang seimbang dan meningkat di perdesaan.

Beberapa kendala yang kerap menaungi kondisi petani mengindikasikan keterbatasan salah satu kelembagaan SDM pertanian, seperti: 1) Tingkat pendidikannya umumnya masih relatif rendah; 2) Sebagian besar petani umumnya belum mampu mengakses diseminasi teknologi sesuai rekomendasi; 3) Belum tergabung atau kurang aktifnya peran kelompok tani; 4) Tujuan pasar hasil pertanian petani umumnya pasar tradisional; 5) Petani belum mengerti atau belum mampu menerapkan strandarisasi mutu produk; 6) Sosialisasi SPO (Standar Prosedur Operasional) perlu diterapkan terutama ke produsen usahatani agar memahami tahapan agroindustri yang 
dilakukan (Bappenas, 2015). Upaya pemberdayaan ke arah pertanian modern selain melalui perubahan struktur ekonomi pertanian, juga menyangkut perubahan struktur dan pola perilaku sosial masyarakat perdesaan untuk mencegah melebarnya gap (kesenjangan) dalam pengembangan pembangunan pertanian melalui agroindustri di perdesaan.

Namun pada pemberdayaan kelembagaan agroindustri perdesaan sering ditemukan terbentuknya interde-pendensi kelembagaan yang mencirikan interaksi sangat asimetris, dinilai tidak menguntungkan bagi perbaikan kualitas ketenagakerjaan (SDM) petani. Kondisi tersebut mencerminkan pendekatan kebijakan perancang pembangunan yang bersifat sentralistik (top down), monolitik dan centrally planned economies (Kozminski, 1990 dalam Elizabeth, 2008), menyebabkan kelembagaan terkesan sulit berkembang dan tidak mengakar pada adat, kebudayaan dan local knowledge masyarakat setempat. Untuk itu, dibutuhkan pembenahan berbagai aspek dan peran keterkaitan antara subsidi 4 faktor, yaitu: 1) sumberdaya; 2) kultural; 3) teknologi; dan 4) kelembagaan/institusi (Induced Innovation Model, Hayami, 1987), dalam proses pemberdayaan dan penguatan jaringan kelembagaan yang berbasis sumberdaya pertanian. Penanganan teknologi usaha agroindustri merupakan salah satu upaya penting dan strategis serta faktor penunjang dalam pengembangan agroindustri di perdesaan.

Untuk memperbaiki kondisi tersebut dibutuhkan aktualisasi pemberdayaan dan pengembangan kelembagaan pertanian, dimulai dari masyarakat tani dan pedesaan supaya: (i) menjadi esensial untuk mencapai kesinergisan optimum dalam aktivitasnya di tingkat lokal; (ii) dapat membantu pemberdayaan ke arah hilirisasi; dan (iii) memudahkan petani mengembangkan sistem kelembagaan usaha agroindustri. Beberapa kendala dalam pengembangan agroindustri, seperti: 1) belum berkembangnya teknologi pengolahan karena masih kecil dan terbatasnya sumber permodalan; 2) rendahnya kualitas tenaga kerja (SDM) dan belum professional; 3) sarana dan prasarana belum memadai; 4) rendahnya jaminan mutu dan kontiniutas (ketersediaan) bahan baku; 5) pemasaran belum berkembang karena produk agroindustribelum memenuhi persyaratan pasar, khususnya pasar internasional; 6) belum adanya kebijakan riil yang 


\section{AKSELERASI HILIRISASI PRODUK AGROINDUSTRI BERDAYASAING MENDONGKRAK \\ KESEJAHTERAAN PETANI DAN EKONOMI PEDESAAN \\ Roosganda Elizabeth, Iwan Setiajie Anugrah}

mendorong

berkembangnya

agroindustridi dalam negeri.

\section{KESIMPULAN DAN IMPLIKASI}

KEBIJAKAN

- Agroindustri sebagai penghela pembangunan pertanian, diharapkan mampu menciptakan pasar berbagai produk pertanian dan produk olahannya, mampu memotori hilirisasi perdesaan, serta mampu menciptakan lapangan kerja dan pendapatan di perdesaan.

- Program pengembangan teknologi dan investasi di perdesaan akan mampu menjadi "mesin penggerak" kemajuan ekonomi yang tangguh, jika sistem kelembagaannya berfungsi sejalan dengan program pembangunan yang dilaksanakan.

- Penerapan inovasi teknologi agroindustri di perdesaan diupayakan memiliki kredibilitas, bisa memberi inspirasi semangat kerja untuk maju, serta kondisi masing-masing daerah (spesifik lokasi) dan di jadikan dasar untuk perancangan pengembangan agroindustri di perdesaan.

- Selain dari sisi finansial, nilai tambah (value added) pengembangan agroindustri di perdesaan juga dapat meningkatkan penyerapan tenaga kerja, meningkatlan pengetahuan dan ketrampilan SDM, terbukanya peluang usaha pengolahan, meningkatnya akses terhadap informasi di luar desa, dan meningkatnya pertumbuhan ekonomi.

- Pengembangan agroindustri bahan pangan di perdesaan perlu disertai oleh program yang langsung menuju ke sasaran (RT petani sebagai subjek), dimana agroindustri dikombinasikan dengan rural development sehingga menjadi satu program pembangunan perdesaan komprehensif.

- Pengembangan teknologi penanganan dan pengolahan produk agroindustri merupakan salah satu faktor penunjang pengembangan dan peningkatan sistem agroindustri bahan pangan di perdesaan, yang terkait dengan pengembangan kelembagaan SDM pelaku pengusahaannya dan berbagai kelembagaan terkait lainnya.

- Dalam perencanaan dan pelaksanaan pembangunan perdesaan, perhatian hendaknya ditekankan pada perbaikan dan pembenahan ragam kelembagaan yang berdayaguna dan berhasilguna serta ke arah peningkatan pendapatan, kesempatan kerja dan berusaha di perdesaan. 
- Kebijakan pemerintah umumnya bias investasi fisik dan permodalan, akan lebih bermanfaat bila diselaraskan dengan pengembangan kelembagaan perdesaan, yang identik dengan perkembangan pertanian, sehingga diharapkan mampu mengakomodasi pengembangan agroindustri.

- Kapasitas dan kinerja kelembagaan perdesaan yang dibentuk nilai-nilai pertanian yang relatif rendah, diprediksi sebagai salah satu kondisi yang dapat menyebabkan rendahnya kinerja perekonomian di perdesaan. Tercapainya hasil pembangunan perdesaan sesuai perencanaan menghendaki pemberdayaan kelembagaan pertanian pertanian.

\section{DAFTAR PUSTAKA}

Balai Besar Industri Agro Bogor (BBIA. Bogor). 2014. Pengembangan Industri Agro di Indonesia. Makalah disampaikan pada Seminar Forum Komunikasi Kelitbangan (FKK) Kementan, Serpong, 14 Mei 2014.

Bahtiar, dan Kindangen, J. G. 2011. Penerapan Rantai Nilai (Value Chain Analysis) dalam Rangka Akselerasi Pembangunan Sektor Pertanian di Sulawesi Utara. Balai Pengkajian Teknologi Pertanian (BPTP) Sulawesi Utara.

Bappenas. 2013. Studi Pendahuluan Rencana Pembangunan Jangka Menengah Nasional (RPJMN) Bidang Pangan dan Pertanian 20152019. Bappenas. Jakarta.
Budijono, A., Yuniarti, Suhardi, Suharjo, dan W. Istuti. 2005. Kajian Pengembangan Agroindustri di Perdesaan. Prosiding Semnas. Inovasi dan Kelembagaan Agribisnis Tahun 2004. hal. 247-254. PSE. Bogor.

Elizabeth. 2018. Akselerasi Agroindustri Dan Nilai Tambah: Faktor Pendukung Pencapaian Dayasaing Produk Dan Percepatan Pembangunan Pertanian Di Indonesia. OJS. Online Jurnal System. UNES (Univ. Ekasakti). Padang. Sumatera Barat.

Elizabeth. 2018a. Akselerasi Pencapaian Dayasaing Produk Agroindustri Melalui Revitalisasi Berkesinambungan Implementasi Pemberdayaan Kelembagaan Pertanian. Buku. Puslitbangtan. Kementerian Pertanian. Jakarta.

Elizabeth. R. 2017. Revitalisasi Industri Produk Olahan Dan Pemberdayaan Lembaga Kemitraan Mendukung Peningkatan Pemasaran, Daya Saing Dan Pensejahteraan Petani Pisang. Journal of Agricultural Scienties. UNES. (Universitas Ekasakti). Padang Sumatera Barat. Volume 2. Issue 1. June 2017. ISSN Cetak: 2528-5556. ISSN Online: 2528-6226.

Elizabeth. R. 2017a. Akselerasi Pemberdayaan Dan Peningkatan Kompetensi Dalam Sistem Produksi Untuk Mengatasi Permasalahan Ekonomi Di Indonesia. Volume 2. Issue 1. June 2017. ISSN Cetak: 2528-5556. ISSN Online: 2528-6226.

Elizabeth, R. 2016. Pemberdayaan Petani Dalam Pengelolaan Tanaman Dan Ternak Guna Meningkatkan Kesejahteraan Petani. Prosiding Seminar Nasional Agustus 2016. BPTP Sulawesi Utara. Manado. Badan Litbang Pertanian. Sekretaris Jenderal Pertanian. Kementerian Pertanian. 


\section{AKSELERASI HILIRISASI PRODUK AGROINDUSTRI BERDAYASAING MENDONGKRAK \\ KESEJAHTERAAN PETANI DAN EKONOMI PEDESAAN \\ Roosganda Elizabeth, Iwan Setiajie Anugrah}

Elizabeth. R. 2015. Pencapaian Daya Saing Melalui Peningkatan Teknologi Pengolahan, Peningkatan Kelembagaan Dan Pemasaran Produk Pangan Olahan. PERHEPI. Tema: Indonesia Menuju Swasembada Pangan Dalam Tiga Tahun Kedepan: "Tinjauan Konseptual, Teoritis dan Empiris". Kendari, 9 Maret, 2015.

Fauzi Azizisep.2014. Hilirisasi Cermin Politik Industri. Bisnis Indonesia. http://www.neraca.co.id/bisnisindonesia. (12 April 2020).

Hadi P. 2014. Reformasi Kebijakan Penciptaan Nilai Tambah Produk Pertanian Indonesia. Reformasi Kebijakan Menuju Trasformasi Pembangunan Pertanian. Haryono (editor). Badan Litbang Pertanian.

Hayami, Y. Kawagoe, T dan Morooka, Y. 1987. Agricultural Marketing and Processing in Upland Java; A Perspektif From A Sunda Village.CGPRT No 8. Bogor.

Hermanto. 2015. General Equilibrium Analysis of the Impact of Climate Change 23 and its Adaptation on Indonesian Agriculture. In Book Economy-Wide Analysis of Climate Change in Southeast Asia: Impact, Mitigation and Trade-off. Published by World Fish (ICLARM) Economy and Environment Program for Southeast Asia (EEPSEA). Philippines.

Hermen, M. 2015. Bangun Industri Desa Selamatkan Bangsa. IPB Press. Majalah pangan XVI, No. 48 Januari 2007, Hal.: 38-49. Jakarta.

John W. and R. Rocha. 2009. Agroindustry Trends, Patterns and Development Impacts. In (edited by) Carlos A. S., D.B. Andrew, S.C. Jenane dan S.M. da-Cruz: AgroIndustries For Development. Published by The Food and Agriculture Organization of the United Nations and The United Nations Industrial Development
Organization by arrangement with CAB International.

Kaniasari, N. 2012. Meningkatkan Nilai Tambah dan Daya Saing Produk Pertanian.

Kusumawardani MH. 2012. Membuat Rantai Nilai Lebih Berpihak Pada Kaum Miskin: Buku Pegangan Bagi Praktisi Analisis Rantai Nilai. Australian Goverment(AU): Aciar. Ignas K. Lidjang, Amirudin P., H.H.Marawali. 2015. Pendekatan Pengembangan Pertanian Bioindustri Berkelanjutan di NTT. Buku "Perspektif Pengembangan Model Pertanian Bioindustri." Badan Litbang Pertanian. Jakarta. IAARD Press. ISBN 978-602-691632-7.

Porter, M. E. 2001. The value chain and competitive advantage. Understanding Business Processes, 1st edn. Routledge.

Porter, M.E. 1998. Competitive Advantage: Creating and Sustaining Superior Performance. New York, Free Press.

Rachmat, M. Prayogo U. H., Sri Nuryanti, Rudy S. R. Herman S., Supadi, Roosganda, E. 2011. Studi Kebutuhan Pengembangan Produk Olahan Pertanian Dalam Rangka Liberalisasi Perdagangan. LHP SINTA. PSEKP. Bogor. Badan Litbang Pertanian. Kementerian Pertanian.

Rafki R. 2015. Analisa Hukum UndangUndang Nomor 3 TAHUN 2014 Tentang Perindustrian. Program Pasca Sarjana Fakultas Hukum Universitas Andalas Padang. https://www.academia.edu/10947813 AANALISA HUKUM UNDANGU NDANG_NOMOR_3 TAHUN 201 4 TENTANG_PERINDUSTRIN $(13$ Januari 2017)

Hayami, Y. dan M. Kikuchi. 1987. Dilema Ekonomi Desa. Suatu Pendekatan Ekonomi Terhadap Perubahan Kelembagaan di Asia. Yayasan Obor. Indonesia. Jakarta. 
Saptana, R. Elizabeth, dkk. 2004. Pemberdayaan Kelembagaan Guna Memperkuat Ekonomi Rakyat di Perdesaan. Journal on SocioEconomics of Agricultural and Agribussines. (Jurnal SOCA). Jurusan Sosial Ekonomi Pertanian. Universitas Udayana. Bali.

Supriyati, E. Suryani, H. Tarigan, A. Setyanto. 2006. Analisis Peningkatan Nilai Tambah Melalui Pengembangan AgroindustriDi Perdesaan. LHP. PSEKP. Bogor Balitbang Pertanian. Departemen Pertanian.

Uphoff, N. 1992. Local Institution and Participation for Sustainable Development. IIED. London. Global Humanitarian Platform. 2013. Principles of Partnership A Statement of Commitment. www.globalhumanitarianplatform.or g
INA (Indonesian Netherlands Association). 2007. Program Dukungan Partnership Usaha Hortikultura antara Petani Produsen Kecil Dengan Perusahaan. Jakarta. www.ina.or.id/inaweb/hpsp.php

Rafki R. 2015. Analisa Hukum UndangUndang Nomor 3 TAHUN 2014 Tentang Perindustrian. Program Pasca Sarjana Fakultas Hukum Universitas Andalas Padang. https://www.academia.edu/10947813/ ANALISA_HUKUM_UNDANGUN DANG_NOMOR_3_TAHUN_2014 TENTANG_PERINDUSTRIAN $(1 \overline{3}$ mei 2020).

Rivani, A. dan D. Hidayat 2007. Keterkaitan Petani dengan Pemasaran: Kesejahteraan Petani dan Pengentasan Kemiskinan. CAPSA Monograph No.49, UNCAPSACAPSA, Bogor. 